\title{
Impact of earthquake-triggered landslides on catchment sediment yield
}

\author{
MATTHIAS VANMAERCKE ${ }^{\mathbf{1}}$, FLORIN OBREJA ${ }^{\mathbf{2}}$ \& JEAN POESEN ${ }^{1}$ \\ 1 Department of Earth and Environmental Sciences, KU Leuven, Celestijnenlaan 200E, 3001 Heverlee, \\ Belgium \\ matthias.vanmaercke@ees.kuleuven.be \\ 2 Hydrology, Hydrogeology and River Forecast Service of SIRET Water Branch, Bacau, Romania
}

\begin{abstract}
This study explores the role of seismic activity in explaining spatial and temporal variation in sediment export from the Siret basin in Romania. Based on long-term ( $>30$ years) sediment export measurements for 38 subcatchments, we found that spatial variation in sediment yield (SY) is strongly correlated to the degree of seismic activity and catchment lithology. Combined, these factors explain $80 \%$ of the variation in SY. To investigate the role of earthquake-triggered landslides in explaining these correlations, we studied the temporal variability in sediment concentrations before and after the $7.4 \mathrm{M}_{\mathrm{w}}$ earthquake of 1977 for ten subcatchments. Despite the fact that this earthquake triggered many landslides, only one subcatchment showed a clear (3-fold) increase in sediment concentration per unit discharge after the earthquake. This shows that, although prolonged seismic activity strongly controls average SY, individual earthquakes do not necessarily affect sediment export at short timescales.
\end{abstract}

Key words sediment yield; earthquake; peak ground acceleration; sediment buffering; rating curves; Romania, Siret

\section{INTRODUCTION}

A growing number of studies show that spatial variation in both erosion rates and contemporary catchment sediment yields (SY, t km${ }^{-2}$ year $^{-1}$ ) are often strongly correlated with seismicity, even in regions with a relatively limited degree of seismic activity and after correcting for autocorrelations with topography and other factors (Dadson et al., 2004; Vanmaercke et al., 2014). The impact of seismic activity on SY may be explained by a number of processes, including earthquake-triggered landsliding (e.g. Dadson et al., 2004; Hovius et al., 2011), an increased susceptibility to weathering and erosion due to co-seismic rock-fracturing (e.g. Molnar et al., 2007) and co-seismic uplift that induces river incision, increased mass wasting and hence an increased sediment output at the catchment scale (e.g. Larsen and Montgomery, 2012). Nonetheless, the relative importance of these processes and the overall influence of seismic activity on SY remains poorly understood.

For example, Hovius et al. (2011) explored the effects of the $7.6 \mathrm{M}_{\mathrm{w}}$ Chi-Chi earthquake in Taiwan on the sediment export by rivers near the epicentre. They stated that, due to co-seismic landsliding, sediment export in the months after the earthquake peaked to more than five times the background rate and returned progressively to pre-earthquake levels in about six years (Hovius et al., 2011). However, Huang and Montgomery (2012) noted no such clear increase in other catchments affected by the earthquake. They also argued that it is very difficult to unambiguously relate these increases in sediment export to earthquake-triggered landslides as the occurrence of typhoons may also provide a plausible explanation (Huang and Montgomery, 2012). Studies focusing on regions other than the exceptionally seismically active, steep and typhoon-affected Taiwan are currently lacking.

Therefore, this study aims to better understand the relationship between seismic activity and sediment export for tributaries of the Siret, a Romanian catchment with strong contrasts in seismicity. The specific objectives are: (i) to quantify the overall importance of seismic activity for explaining spatial variation in average SY within the Siret; and (ii) to explore the direct impacts of a large $\left(7.4 \mathrm{M}_{\mathrm{w}}\right)$ earthquake on short-term ( $<5$ years) sediment export.

\section{STUDY AREA}

This study focuses on subcatchments of the $45000 \mathrm{~km}^{2}$ Siret basin in Romania (Fig. 1). Part of the Siret basin (the 'Vrancea region') is characterized by important neo-tectonic movements and is one 


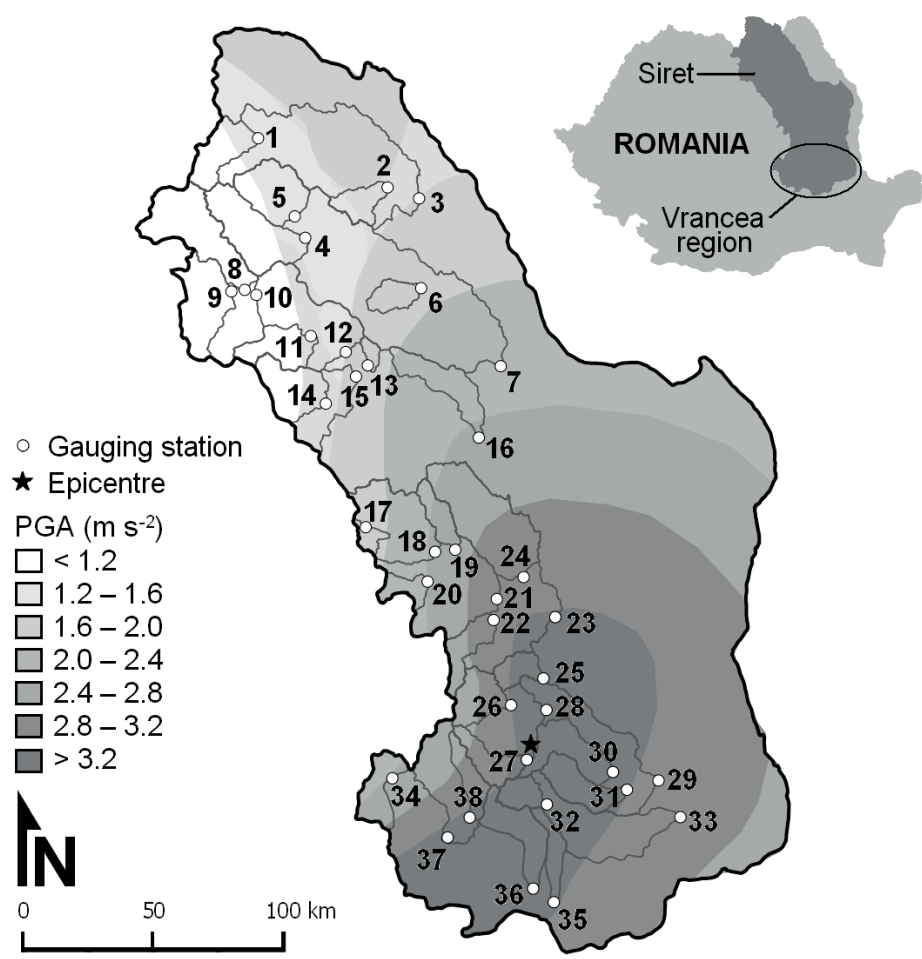

\begin{tabular}{cccc}
\hline Nr. & Gauging Station & A $\left(\mathrm{km}^{2}\right)$ & Dominant Lithology \\
\hline 1 & Brodina & 366 & Flysch \\
2 & Părhăuți & 204 & Platform \& Quaternary \\
3 & Itcani & 2334 & Platform \& Quaternary \\
4 & Prisaca Dornei & 664 & Crystalline \\
5 & Dragoșa & 463 & Flysch \\
6 & Bogdănești & 181 & Flysch \\
7 & Tupilați & 3928 & Flysch \\
8 & Dorna Giumalău & 758 & Crystalline \\
9 & Dorna Candreni & 565 & Volcanic \\
10 & Dorna Arini & 1690 & Crystalline \\
11 & Broșteni & 292 & Crystalline \\
12 & Frumosu & 2858 & Crystalline \\
13 & Poiana Largului & 59 & Flysch \\
14 & Tulghes & 408 & Crystalline \\
15 & Bistricioara & 760 & Crystalline \\
16 & Slobozia & 445 & Molasse \\
17 & Lunca de Sus & 88 & Flysch \\
18 & Goioasa & 781 & Flysch \\
19 & Asău & 204 & Flysch \\
20 & Valea Uzului & 150 & Flysch \\
21 & Târgu Ocna & 2091 & Flysch \\
22 & Ferăstrău & 267 & Flysch \\
23 & Vrânceni & 4092 & Flysch \\
24 & Helegiu & 998 & Molasse \\
25 & Ciuruc & 178 & Molasse \\
26 & Tulnici & 313 & Flysch \\
27 & Nereju & 263 & Flysch \\
28 & Colacu & 1087 & Flysch \\
29 & Botârlău & 2450 & Platform \& Quaternary \\
30 & Golesti & 406 & Molasse \\
31 & Jiliste & 398 & Platform \& Quaternary \\
32 & Tulburea & 187 & Molasse \\
33 & Tătaru & 1048 & Platform \& Quaternary \\
34 & Sita Buzău & 360 & Flysch \\
35 & Potârnichești & 194 & Molasse \\
36 & Cernătesti & 422 & Molasse \\
37 & Bâsca Rożilei & 783 & Flysch \\
38 & Varlaam II & 239 & Flysch \\
\hline & & &
\end{tabular}

Fig. 1 Map of the Siret basin, the 38 subcatchments considered in this study and the epicentre of the $\mathrm{M}_{\mathrm{w}}$ 7.4 earthquake of 1977. 'PGA' indicates the expected Peak Ground Acceleration with a recurrence interval of 100 years (Lungu et al., 2004). 'A' indicates the contributing area of each subcatchment.

of the most seismically active regions of Europe. Since 1900, over 500 significant $\left(\mathrm{M}_{\mathrm{w}}>4\right)$ earthquakes were registered in the region, including four major $\left(\mathrm{M}_{\mathrm{w}}\right.$ 6.9-7.6) earthquakes (NIEP, 2012). The epicentres of most of these earthquakes are confined to a relatively small region of 40 by $80 \mathrm{~km}$ (Fig. 1) and are located at a depth of 60 to $180 \mathrm{~km}$ (NIEP, 2012).

The Siret basin is characterized by several lithological units. From west to east, these include volcanic and crystalline rock, flysch, Molasse and Quaternary sediments (marls, clay, sands, loess, sandstones and limestone). Overall, relief within the catchment decreases from west to east and from north to south. Altitude ranges between about 10 and $2100 \mathrm{~m}$ a.s.l., while the basin has a mixed land use which is also linked to the lithology: agriculture is mainly practiced on the plateaus and lowland areas having a lithology of Molasse or Quaternary sediments. The mountainous areas with flysch, volcanic and crystalline rocks are mainly forested.

Mean annual precipitation in the catchment varies between 650 and $1000 \mathrm{~mm}$ in the mountainous areas and 380 to $600 \mathrm{~mm}$ in the plateau and lowland areas and is characterised by a large temporal variability. As a result, river discharges are regularly affected by both prolonged periods of low runoff as well as large floods (Obreja, 2012).

\section{MATERIALS AND METHODS}

To address the first objective of this study, 38 subcatchments of the Siret basin were selected for which measured suspended sediment export data were available for a period of at least 30 years (Fig. 1). Runoff and sediment discharge in these catchments was not significantly affected by reservoirs or lakes. Hydrological and sediment export measurements were conducted by Siret River Water Branch and Buzau-Ialomita Water Branch from the "Romanian Water" National Administration. Daily average runoff discharge $\left(Q, \mathrm{~m}^{3} \mathrm{~s}^{-1}\right)$ was based on at least two runoff discharge observations per day. Suspended sediment concentration $\left(S S C, \mathrm{~g} \mathrm{~L}^{-1}\right.$ ) was measured at a flow proportional basis: SSC was measured at least weekly during periods of low flow and daily or even hourly during flood events. For days without SSC measurement, SSC was estimated based on time interpolations. Average SY was calculated based on the integration of these daily $Q$ and $S S C$ values. 
For each catchment, several characteristics were determined describing its size, climatic conditions, topography, lithology and land use. Most of these variables were also used in previous studies aiming to identify the factors controlling SY (e.g. Syvitski and Milliman, 2007; de Vente et al., 2013; Vanmaercke et al., 2014). To quantify the overall degree of seismic activity, the spatial average of the expected Peak Ground Acceleration with a recurrence interval of 100 years (PGA; Lungu et al., 2004) was calculated for each catchment. The relative importance of these characteristics in explaining spatial variation in SY was explored by means of correlation analyses. To account for potential inter-correlations, partial correlation analyses were also conducted. Partial correlation measures the degree of association between two variables, with the effect of other controlling variables removed (Fisher, 1924; Steel and Torrie, 1960).

To address the second objective of this study, we analysed the temporal variation in SSC during the five years before and after the $M_{w} 7.4$ earthquake of 4 March 1977 for ten subcatchments of the Siret. Average distances of these catchments to the earthquake epicentre ranged from 16 to $258 \mathrm{~km}$.

Assessing the effect of an earthquake on the temporal variation in sediment export requires that the inherent day-to-day variability in sediment export is also taken into account. One may expect that consistent changes in sediment supply and transport will be reflected as differences in the parameters of sediment rating curves (Asselman, 2000; Vanmaercke et al., 2010; Hovius et al., 2011). We therefore compared fitted parameters of sediment rating curves of the type:

$$
S S C=a Q^{b}
$$

where $a$ and $b$ are the fitted coefficient and exponent of the rating curve. For each of the ten subcatchments, this was done by first fitting equation (1) using all available daily $Q$ and $S S C$ values up to five years before the earthquake. Next, we grouped all $Q$ and $S S C$ values up to five years before and after the earthquake into ten 'hydrological years' which ran from 4 March (i.e. the day of the 1977 earthquake) until 3 March the next year. For each of these hydrological years, we fitted a rating curve using the same $b$ exponent as was obtained based on all data from the five years before the earthquake (i.e. only the $a$ coefficient of the rating curve was fitted to the $Q$ and SSC observations of the considered hydrological year). A similar approach was followed by Hovius et al. (2011). All rating curves were fitted, using a non-linear regression procedure.

\section{RESULTS AND DISCUSSION}

Our (partial) correlation analyses showed that average SY was strongly correlated with seismic activity (PGA) and catchment lithology (L; an area-weighted scoring factor calculated according to a method proposed by Syvitski and Milliman, 2007). Although L and PGA are also intercorrelated, partial correlation analyses showed that each of these factors explained a significant fraction of the observed variability in SY that could not be attributed to other factors.
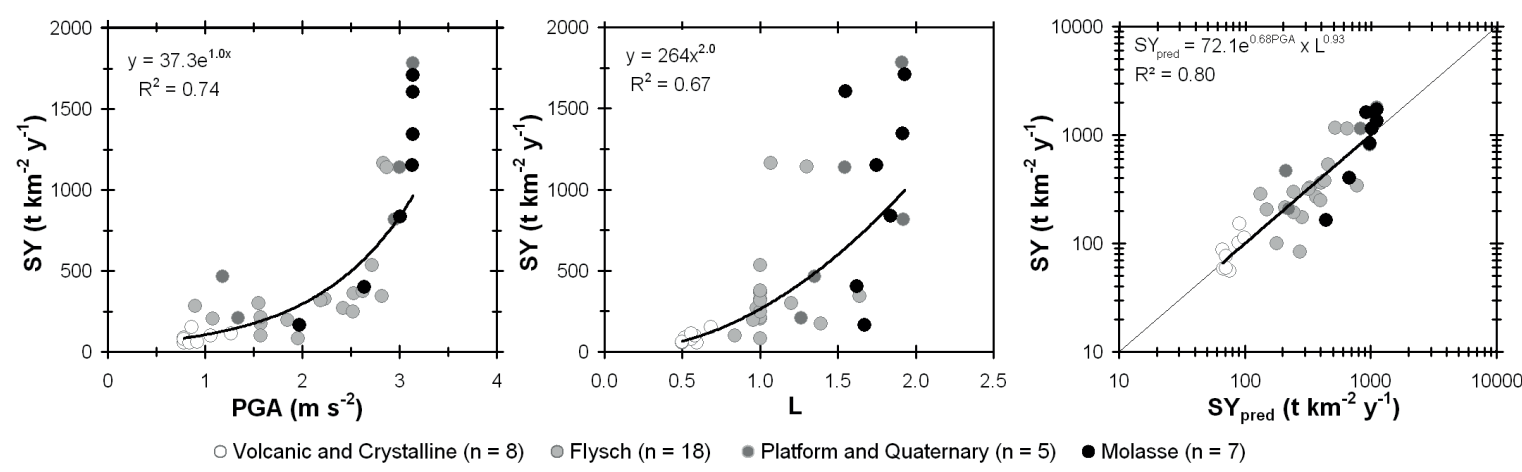

Fig. 2 Average observed sediment yield (SY) versus PGA (the Peak Ground Acceleration with a recurrence interval of 100 years), L (a catchment lithology erodibility factor as defined by Syvitski and Milliman, 2007) and SY pred (an empirical regression model based on L and PGA and calibrated on the 38 selected subcatchments of the Siret; Fig. 1). 
Combined, PGA and L alone explained $80 \%$ of the observed variability in SY on a log-log scale (Fig. 2). On a linear scale, the goodness of fit was somewhat lower $\left(\mathrm{SY}=1.19 \times \mathrm{SY}_{\text {pred, }} \mathrm{R}^{2}=0.77\right)$.

Surprisingly, other factors related to land use, topography, rainfall and runoff did not significantly contribute to the explained variance. To some extent, this may be attributed to the relatively small number of catchments $(\mathrm{n}=38)$ involved and uncertainties on both the considered parameters and the obtained SY-values. However, topographic measures (e.g. average catchment slope, mean local relief) even showed negative correlations with SY. These became insignificant after their (also negative) inter-correlations with seismic activity were taken into account. These results may seem counter-intuitive, but they mainly illustrate that seismic activity can have a very strong influence on SY that is not reflected by catchment topography. This concurs with the findings of several recent studies (e.g. de Vente et al., 2013; Vanmaercke et al., 2014). As the case of the Siret River demonstrates, seismic activity may even counteract the commonly expected positive correlation between SY and topography. We therefore argue that seismicity should be considered explicitly in models aiming to simulate SY.

Figure 3 shows the year-to-year variability in the $a$ coefficient of equation (1) up to five hydrological years before and after the earthquake of 1977. Only one of the ten selected subcatchments (Nereju) shows a clear and consistent increase (of $a$ ) in the years after the earthquake. The other catchments showed no convincing increase or even a decrease. While the Nereju catchment was located very near to the earthquake epicentre, several other catchments were located at a similar distance (Fig. 1). Also, additional analyses (including analyses of the daily variability of $Q$ and $S S C$ ) revealed no clear impact of the earthquake on sediment export or sediment concentrations.

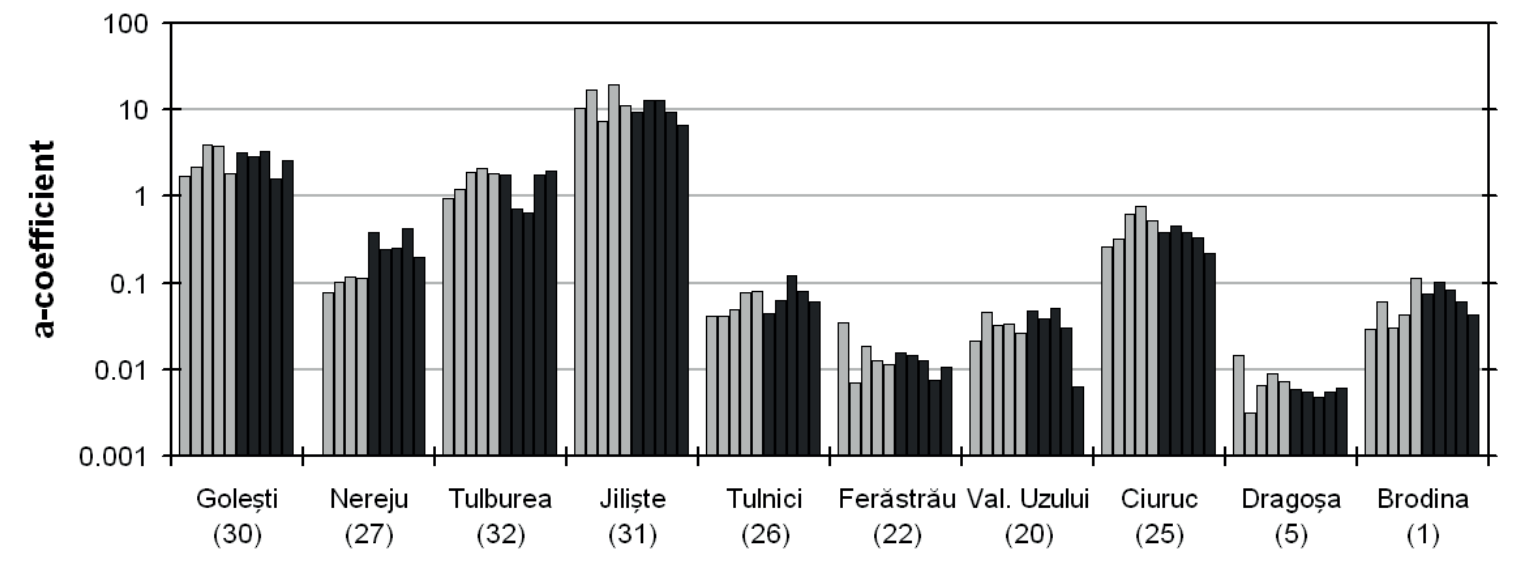

Fig. $3 a$ coefficients of the sediment rating curves (equation (1)) for the five consecutive hydrological years before (light grey) and after (dark grey) the $M_{w} 7.4$ earthquake of 4 March 1977. The gauging stations are ordered according to their increasing distance from the epicentre (numbers correspond with those on Fig. 1). Note that only Nereju shows a consistent increase in $a$ coefficient after the earthquake.

Although a complete inventory of landslides triggered by the 1977 earthquake is lacking, it is certain that this earthquake caused a substantial number of landslides. Bălteanu (1979) mapped the occurrence of landslides before and after the 1977 earthquake in a small region close to the epicentre and reported 20- to 50-fold increases in landsliding due to this event. Our results therefore raise two important questions. Firstly: why does such a significant landslide-triggering earthquake event have (almost) no distinguishable impact on the suspended sediment export in the years after this event? Secondly: if a major landslide-triggering earthquake has no clear impact on the temporal variability of suspended sediment export, why do we observe such a strong spatial correlation between seismic activity and average SY at the decadal scale?

As to the first question, several reasons may explain why suspended sediment export is not affected by large earthquake-triggered landslide events. Firstly, other studies suggest that often only a small fraction of the occurring landslides will directly contribute to catchment sediment 
export due to a lack of sediment connectivity (e.g. de Vente et al., 2006; Cavalli et al., 2013). Some studies also indicated that earthquake-triggered landslides are often located at higher positions on hillslopes, and hence further away from the river channel, compared to rainfall-triggered landslides (e.g. Meunier et al., 2008). Hence, the connectivity between earthquake-triggered landslides and sediment exporting rivers might overall be even smaller than for rainfall-triggered landslides. Secondly, it should be noted that this study only considered suspended sediment export, whereas many earthquake-triggered landslides often mainly consist of coarser sediments (i.e. gravel and boulders; Keefer, 2002). Such landslides would have only a limited direct impact on the suspended sediment load, even if they reach the river system. A third reason may be the occurrence of delays between the earthquake and its associated landslides. Earlier studies reported that landslides associated with a large earthquake event can occur months after the considered earthquake and may be triggered by a rainfall or smaller earthquake event (e.g. Keefer, 2002; Hovius et al., 2011). Likewise, Lin et al. (2006a) demonstrated that the spatial extent of landslides triggered by an earthquake can substantially increase due to rainfall events after the earthquake, leading to a gradual rather than a sudden increase in suspended sediment export.

This last reason also provides a potential answer to our second question. The occurrence of earthquakes in the Vrancea region (Fig. 1) does not necessarily result in clear and distinct landslide events that cause pulses in sediment export, but more likely in an overall larger supply of sediments due to landslides. Based on a review of studied earthquake-triggered landslide events, Malamud et al. (2004) indicate that earthquake-triggered mass movements may occur from earthquakes with $\mathrm{M}_{\mathrm{w}}>4$. Such earthquakes occur frequently in Vrancea (530 earthquakes between 1900 and 1977; NIEP, 2012). Also a nation-wide analysis of landslides in Romania showed that the Vrancea region is overall very susceptible to landsliding due to its overall high rate of seismic activity (Bălteanu et al., 2010). This, in combination with the possibility that landslides are not always triggered directly by the earthquake, may help explain why long-term average SY is strongly correlated with seismic activity (Fig. 2) while a single major earthquake event shows no clearly identifiable impact on the temporal variability of sediment export (Fig. 3).

There are additional reasons why earthquake-triggered landslides may affect long-term average SY but are not necessarily reflected in the temporal variations in sediment export. For example, areas that are affected by recent landslides are often devoid of vegetation and therefore prone to various other water erosion processes. Lin et al. (2006b) report six-fold increases in sheet and rill erosion rates due to this effect. As the vegetation recovery of landslide-affected areas often requires several years (Lin et al., 2006b), this increased susceptibility to water erosion processes may lead to an increase in average SY. Furthermore, it should be acknowledged that, apart from earthquake-triggered landsliding, other processes may also contribute to the observed strong correlation between seismic activity and average SY (Fig. 2). As indicated in the introduction, coseismic uplift and rock fracturing can also lead to increased erosion rates and, hence, average SY (e.g. Molnar et al., 2007; Larsen and Montgomery, 2012). It should also be noted that these different possible explanations may reinforce each other. For example, both tectonic uplift and seismic rock fracturing may lead to an increased susceptibility to earthquake-triggered landsliding. Nonetheless, the importance of these different mechanisms and their potential interactions are currently poorly understood (e.g. Molnar et al., 2007; Vanmaercke et al., 2014).

\section{CONCLUSIONS}

This study demonstrated that differences in average annual catchment sediment yield (SY) in the Siret basin (Fig. 1) are mainly explained by the overall degree of seismic activity (expressed as PGA) and the catchment lithology (Fig. 2). Evidently, these results should be interpreted with caution, since they were based on the analyses of a fairly limited number of catchments $(n=38)$ in one specific region, that represented important differences in seismic activity. However, they illustrate that seismic activity may exert a stronger impact on SY than many other factors that are commonly considered in SY models. We therefore argue that it is highly relevant to also explicitly consider seismic activity when explaining or predicting regional variation in SY. 
The direct impact of a large earthquake event on sediment export proved to be much more difficult to detect. Based on other recent research, it was expected that, due to earthquake-triggered landsliding, a major earthquake would be followed by a detectable pulse of increased sediment export. Despite the fact that the $7.4 \mathrm{M}_{\mathrm{w}}$ earthquake of 1977 caused a substantial number of landslides, nine out of ten studied subcatchments showed no clear increase in suspended sediment export after the earthquake (Fig. 3). This suggests that earthquake-triggered landslides affect SY mainly in an indirect way or that observed correlations between SY and seismic activity are (partly) due to other processes than earthquake-triggered landsliding (e.g. tectonic uplift and rock fracturing).

\section{REFERENCES}

Asselman, N. (2000) Fitting and interpretation of sediment rating curves. J. Hydrol. 234, 228-248.

Bălteanu, D. (1979) Procese de modelare a versanţilor declanşate de cutremurul din 4 martie 1977 în Carpaţii şi Subcarpaţii Buzăului, $S C G G G$, seria Geografie, t.26, Bucureşti.

Bălteanu, D., et al. (2010) A country-wide spatial assessment of landslide susceptibility in Romania. Geomorphology 124, 102112 .

Cavalli, M., et al. (2013) Geomorphometric assessment of spatial sediment connectivity in small Alpine catchments. Geomorphology 188, 31-41.

Dadson, S., et al. (2004) Earthquake-triggered increase in sediment delivery from an active mountain belt. Geology 32, 733736.

de Vente, J., et al. (2006) Predicting catchment sediment yield in Mediterranean environments: the importance of sediment sources and connectivity in Italian drainage basins. Earth Surface Processes and Landforms 31, 1017-1034.

de Vente, J., et al. (2013). Predicting soil erosion and sediment yield at regional scales: where do we stand? Earth-Science Reviews 127, 16-29.

Hovius, N., et al. (2011) Prolonged seismically induced erosion and the mass balance of a large earthquake. Earth and Planetary Science Letters 304, 347-355.

Huang, M. Y. F. and Montgomery, D. R. (2012). Fluvial response to rapid episodic erosion by earthquake and typhoons, Tachia River, central Taiwan. Geomorphology 175-176, 126-138.

Keefer, D. K. (2002) Investigating landslides caused by earthquakes-a historical review. Surveys in Geophysics 23(6), 473-510.

Larsen, I.J. and Montgomery, D.R. (2012) Landslide erosion coupled to tectonics and river incision. Nature Geoscience 5, $468-473$.

Lin, J.-C., et al. (2006a) Slope movements in a dynamic environment - A case study of Tachia River, Central Taiwan. Quaternary International 147, 103-112.

Lin, W.-T., Lin, C.-Y. and Choun W.-C. (2006b) Assessment of vegetation recovery and soil erosion at landslides caused by a catastrophic earthquake: A case study in Central Taiwan. Ecological Engineering 28, 79-89.

Lungu, D., et al. (2004) Representation of seismic action in the new Romanian code for design of earthquake resistant buildings P100-2003. 13th World Conference on Earthquake Engineering Vancouver, BC, Canada, 1-6 August 2004, Paper No. 1796.

Malamud, B. D., et al. (2004) Landslides, earthquakes, and erosion. Earth and Planetary Science Letters 229(1), 45-59.

Meunier, P., Hovius, N. and Haines, J.A. (2008) Topographic site effects and the location of earthquake induced landslides. Earth and Planetary Science Letters 275, 221-232.

Molnar, P., Anderson, R.S. and Anderson, S.P. (2007) Tectonics, fracturing of rock, and erosion. Journal of Geophysical Research 112, F03014, doi: 10.1029/2005JF000433.

National Institute for Earth Physics, Romania (NIEP) (2013) Romplus Catalogue, 2013. Available online: http://www.infp.ro/catalog-seismic/evenimente.

Obreja, F. (2012) The sediment transport of the Siret River during the floods from 2010. Forum geographic, Studii şi cercetări de geografie şi protecţia mediului, XI (1), 90-99.

Syvitski, J.P.M. and Milliman, J. (2007). Geology, Geography, and Humans Battle for Dominance over the Delivery of Fluvial Sediment to the Coastal Ocean. The Journal of Geology 115, 1-19.

Vanmaercke, M., et al. (2010) Sediment dynamics and the role of flash floods in sediment export from medium-sized catchments: a case study from the semi-arid tropical highlands in northern Ethiopia. J. Soils Sediments 10, 611-627.

Vanmaercke, M., et al. (2014) Moderate seismic activity affects contemporary sediment yields. Progress in Physical Geography 38, 45-172. 